\title{
7: 50624473-50434254
}

National Cancer Institute

\section{Source}

National Cancer Institute. 7: 50624473-50434254. NCI Thesaurus. Code C42422.

Physical location of GRB10_Gene 